FOLIA POMERANAE UNIVERSITATIS TECHNOLOGIAE STETINENSIS

Folia Pomer. Univ. Technol. Stetin., Oeconomica 2019, 353(95)2, 5-16

Iwona BĄK, Katarzyna WAWRZYNIAK*, Antoni SOBOLEWSKI**

\title{
THE IMPACT OF THE UNEMPLOYED POPULATION STRUCTURE ON THE LEVEL OF EMPLOYMENT EFFECTIVENESS ${ }^{1}$
}

\author{
Department of Mathematical Economics, West Pomeranian University of Technology in Szczecin, \\ Klemensa Janickiego 31, 71-270 Szczecin, Poland, ORCID: 0000-0001-8959-7269, \\ e-mail: iwona.bak@zut.edu.pl \\ *Department of Mathematical Economics, West Pomeranian University of Technology in Szczecin, \\ Klemensa Janickiego 31, 71-270 Szczecin, Poland, ORCID: 0000-0003-4161-3877, \\ e-mail: katarzyna.wawrzyniak@zut.edu.pl \\ **Stowarzyszenie Czas Przestrzeń Tożsamość, Lwowska 3/1, 71-027 Szczecin, Poland, \\ ORCID: 0000-0001-7835-7104
}

\begin{abstract}
Summary. The purpose of the article is to evaluate the extent to which the registered unemployed population structure analyzed by selected categories of demographic characteristics affects the employment efficiency index. The coefficients of Pearson correlation and multiple correlation between the employment efficiency index and demographic characteristics were used as research tools. The coefficients were calculated for county labor offices operating in the individual Voivodships in 2018, and were used to detect regularities regarding the correlations between these magnitudes for the individual voivodships. It turned out that the research failed to render unequivocal results. The strength of the relationships between the examined variables at the country level (for all county labor offices) was far lower than that observed for the individual Voivodships. Each Voivodship appeared to demonstrate a different set of demographic features having a significant impact on the employment efficiency index, while the directions of such impact frequently varied between the Voivodeships, as well.
\end{abstract}

Key words: correlation analysis, county labor offices, structure of the unemployed population, employment efficiency index.

\section{INTRODUCTION}

On an annual basis, the Polish Ministry of Family, Labor and Social Policy publishes a report on the efficiency of major forms of stimulating vocational activity on its website ${ }^{2}$. The report analyzes the efficiency with which county labor offices utilize the given year's Labor Fund money to finance major methods designed to stimulate vocational activity such as training courses, job creation partnerships, public works, internships, reimbursement of the costs

\footnotetext{
1 The article was written as part of the project titled: „Wypracowanie metodologii i wdrożenie monitorowania efektywności zatrudnieniowej podstawowych form aktywizacji zawodowej bezrobotnych w okresie dłuższym niż 12 miesięcy od zakończenia działań urzędu pracy" conducted by Stowarzyszenie Czas Przestrzeń Tożsamość (an implementation project co-financed by the European Social Fund under the Operational Programme Knowledge Education Development, Priority Axis: II. Effective public policies for the labour market, economy and education, Action 2.4 - Modernisation of public and private employment services, and improving the matching of labour market needs).

2 The website, https://www.gov.pl/web/rodzina/efektywnosc-form-promocji-zatrudnienia contains reports for 2008-2018 along with attachment containing data across Voivodeships and county labor offices, accessed on: 24.10.2019.
} 
incurred on furnishing or retrofitting the workplace to unemployed persons assigned to such workplaces, or one-off subsidies to persons setting up a business ${ }^{3}$. Every such report informs of, inter alia, the number of people successfully stimulated through such major stimulation methods, and of the employment and cost efficiency of the major stimulation forms in selected years ${ }^{4}$ and in the individual Voivodeships in the given years, whereas the employment and cost efficiency are analyzed both in general (accounting for all the major vocational stimulation forms) and for each such form separately. Moreover, a ranking of Voivodeships is presented every year that ranks them by the value of their employment and cost efficiency indexes (both generally and separately for each stimulation form) and divides them into groups of those above and below the national average index. On this basis, an assessment is made of the effectiveness of the given Voivodeship's county labor offices. As this assessment draws on efficiency index values, the manner in which the efficiency of labor market services and instruments is measured is of crucial importance. Many papers have been published both in Poland and other European countries presenting organizational, legal and methodological aspects of efficiency measurement - cf., inter alia, the papers authored by Kluve et al. (2005), Kluve (2006), Efektywność usług... (2008), Efektywność polityki... (2011), Metody i narzędzia... (2012), Escudero (2015), or Analiza rozwiązań... (2017).

Some authors have published results of studies of differing efficiency index levels between Voivodeships (e.g. Reichelt 2007; Cicha-Nazarczuk 2015; Knapińska 2015; Bieszk-Stolorz, Dmytrów 2018; Bąk et al. 2018). One of the main conclusions drawn from these studies is that such differences are caused by various factors characterizing the socio-economic situation found in the studied region.

As surveys among representatives of public employment services have shown (Badanie ilościowe... 2018), the level of the employment efficiency index is largely dependent on the characteristics of the unemployed persons registered within the jurisdiction of the given county labor office. Therefore, assessments of the effectiveness of county labor offices based on an aggregate value for the whole Voivodeship will not always be reliable. This in particular applies to those Voivodeships that operate a large number of county labor offices, for which the degree of diversity of their unemployed in terms of sex, educational background, age or duration of unemployment can be very significant. This in turn - according to representatives of public employment services - translates into difficulties getting the unemployed back to work in an open labor market, especially where the area covered by the given county labor office is dominated by unqualified unemployed persons, long-term unemployed persons or jobless persons aged 55 or more.

The significance of this problem is such that a decision was made to carry out a study, the results of which are published in this paper, aiming at verifying the degree to which the structure of the registered unemployed population according to selected demographic characteristics affected the level of the employment efficiency index. The coefficients of Pearson correla-

\footnotetext{
${ }^{3} \mathrm{~A}$ catalogue of major vocational stimulation forms, understood as labor market services and instruments financed under the Labor Found, is published annually by the minister responsible for employment matters on the ministry's website (Ustawa z dnia 20 kwietnia 2004 r. o promocji...).

${ }^{4}$ In the paper that pertained to 2018, the selected years covered the period from 2014 to 2018 (Efektywność podstawowych form..., 2019, 9-11).
} 
tion and multiple correlation between the employment efficiency index and selected demographic characteristic categories were used as research tools. These coefficients were determined for county labor offices operating within the individual Voivodeships in order to detect any regularities within the correlations between these magnitudes in the given Voivodeships.

The study covered Poland's 340 county labor offices in 2018.

\section{MATERIAL AND METHOD}

Poland had 340 county labor offices in 2018 , including:

- 276 offices operating within rural counties usually incorporating several municipalities, which comprise rural areas and small towns,

- 25 offices operating within urban counties, which are cities enjoying county status,

- 39 offices operating within rural and urban counties comprising - beside rural municipalities and small towns - also cities enjoying county status.

For each county labor office, statistical data on the overall employment efficiency indexes (Polish acronym EZ) and selected indicators characterizing the unemployed population structure found within the office's jurisdiction were gathered. In the case of the overall employment efficiency index, construed as a percentage of people who during or after their participation in major vocational stimulation forms were shown as employed persons against the population who have completed their participation in major vocational stimulation forms (Ustawa $z$ dnia 20 kwietnia 2004 r. o promocji...) - the data were derived from the publication titled (Efektywność podstawowych form... 2019). As for information on the indicators characterizing the unemployed population structure, it was derived from the GUS Local Data Bank and for 39 offices - operating within rural and urban counties - the values of the indicators were calculated by aggregating relevant data coming from the studied regions. Due to the very high number of indicators characterizing the registered unemployed population structure that are published by public statistics services, the decision was made to only use in the study such indicators whose significant impact on the employment efficiency index was signaled by representatives of the public employment services (Badanie ilościowe... 2018). The names and symbols of selected indicators characterizing the unemployed according to such main demographic feature categories as sex, educational background, age, domicile, duration of unemployment, are shown below:

- sex - share of unemployed women in the total unemployed population ( $X_{1}$ in \%);

- educational background - share of unemployed persons with tertiary education in the total unemployed population $\left(X_{2}\right.$ in \%), share of unemployed persons with basic vocational education in the total unemployed population $\left(X_{3}\right.$ in $\left.\%\right)$, share of unemployed persons with junior high school or lower education in the total unemployed population $\left(X_{4}\right.$ in \%);

- age - share of unemployed persons aged 24 or less in the total unemployed population $\left(X_{5}\right.$ in \%), share of unemployed persons aged 55 or more in the total unemployed population $\left(X_{6}\right.$ in \%);

- domicile - share of unemployed persons from rural areas in the total unemployed population $\left(X_{7}\right.$ in $\left.\%\right)$; 
- duration of unemployment - share of unemployed persons remaining jobless for 12 to 24 months in the total unemployed population $\left(X_{8}\right.$ in \%), share of unemployed persons remaining jobless for over 24 months in the total unemployed population ( $X_{9}$ in \%);

- additional indicators describing unemployed in special situations in the labor market - share of unemployed persons aged 18-24 remaining jobless for more than 6 months in the total unemployed population ( $X_{10}$ in \%), share of unemployed persons aged 55-64 remaining jobless for more than 12 months in the total unemployed population $\left(X_{11}\right.$ in \%), share of unemployed persons aged 55-64 remaining jobless for more than 12 months in the total 55-64-year-old unemployed population ( $X_{12}$ in \%), share of unemployed persons without qualifications (without seniority) in the total unemployed population $\left(X_{13}\right.$ in \%), share of disables unemployed people in the total unemployed population $\left(X_{14}\right.$ in $\left.\%\right)$.

The Pearson correlation coefficient $\left(r_{y x_{j}}\right)$ was used in order to discover regularities in respect of the strength and direction of the relationships between the employment efficiency $(E Z)$ indicator and the specific indicators characterizing the unemployed persons within the jurisdiction of the county labor offices, and the multiple correlation indicator $\left(R_{y \cdot x_{1}, x_{2}, \ldots, x_{k}}\right)$ was used to describe the combined impact of these indicators on the employment efficiency index. These indicators were calculated using the following formulae ${ }^{5}$ :

$$
\begin{gathered}
r_{y x_{j}}=\frac{\sum_{i=1}^{n}\left(x_{i j}-\bar{x}\right) \cdot\left(y_{i}-\bar{y}\right)}{S\left(x_{j}\right) \cdot S(y)} \\
R_{y \cdot x_{1}, x_{2}, \ldots, x_{k}}=\sqrt{1-\frac{\operatorname{det} R_{n}}{\operatorname{det} R_{m}}}
\end{gathered}
$$

where:

$y_{i}$ - value of the employment efficiency (EZ) index in the $i$-th county labor office;

$x_{i j}$ - value of the $j$-th indicator characterizing the unemployed population structure within the jurisdiction of the $i$-th county labor office;

$R_{n}$ - matrix of the coefficients of Pearson correlation between the studied variables, which also include the employment efficiency index (dependent variable) and all indicators characterizing the unemployed population structure (independent variables);

$R_{m}$ - matric of the coefficients of correlation only between the independent variable,

i.e. the indicators characterizing the unemployed population structure;

$\operatorname{det} R_{n}$ - determinant of matrix $R_{n}$;

$\operatorname{det} R_{m}$ - determinant of matrix $R_{m}$.

Since the study discussed in this paper was a full one, those relationships whose correlation coefficients were at a level of at least 0.3 were deemed as significant. In order to substantiate the correlation coefficient level adopted for the interpretations, sample value ranges of the correlation coefficient that are well-known in the literature along with indications of the magnitude of the relationships have been shown in Table 1. The table suggests that, according to the three authors, the relationship between the characteristics is at least moderate (definite) if the correlation coefficient is larger than 0.3.

${ }^{5}$ These formulae can be found in the papers by, inter alia, Luszniewicz and Słaby (2003), Statystyka (2005), Bąk et al. (2018). 
Table 1. The magnitude of correlations between the characteristics for the Pearson correlation coefficient according to selected authors

\begin{tabular}{|c|c|c|c|c|c|c|c|}
\hline \multicolumn{2}{|c|}{ J.P. Guilford (1964) } & \multicolumn{2}{|c|}{ A. Góralski (1976) } & \multicolumn{2}{|c|}{ L. A. Gruszczyński (1986) } & \multicolumn{2}{|c|}{ K. Zając (1982) } \\
\hline$r<0.2$ & slight & $r=0$ & none & $0<r \leq 0.2$ & $\begin{array}{l}\text { very slight, } \\
\text { indefinite }\end{array}$ & $r \leq 0.3$ & indefinite \\
\hline $0.2<r<0.4$ & low & $0<r<0.1$ & & $0.2<r \leq 0.3$ & slight & $0.3<r<0.5$ & medium \\
\hline $0.4<r<0.7$ & moderate & $0.1<r<0.3$ & slight & $0.3<r \leq 0.5$ & $\begin{array}{l}\text { definite with } \\
\text { moderate } \\
\text { intensity }\end{array}$ & $r \geq 0.5$ & definite \\
\hline $0.7<r<0.9$ & high & $0.3<r<0.5$ & moderate & $0.5<r \leq 0.7$ & strong & & \\
\hline $0.9<r<1.0$ & very high & $0.5<r<0.7$ & high & $0.7<r<1.0$ & very strong & & \\
\hline & & $0.7<r<0.9$ & very high & & & & \\
\hline & & $0.9<r<1.0$ & $\begin{array}{l}\text { almost } \\
\text { full }\end{array}$ & & & & \\
\hline & & $r=1.0$ & full & & & & \\
\hline
\end{tabular}

Source: Developed by the authors based on: Guilford (1964); Góralski (1976); Gruszczyński (1986); Zając (1982).

\section{RESULTS}

Table 2 demonstrates the values of the correlation coefficients and the multiple correlation coefficient calculated based on data on the overall employment efficiency index and the indicators characterizing the unemployed population for all the 340 county labor offices, and for the county labor offices operating within the individual Voivodeships - those correlation coefficient values that amounted to at least 0.3 are shown in bold type.

The analysis of the results shown in Table 2 was started with the multiple correlation coefficient the level of which allowed for assessing the strength of the combined impact of selected demographic characteristics on the level of the employment efficiency index. Its values - depicted in the last column of Table 2 - reflected a very strong combined impact of the selected demographic characteristics on the employment efficiency index, as in all the Voivodeships for which that coefficient could be calculated its value exceeded 0.7 . This meant that at least to the extent of $49 \%$ the variance of the employment efficiency index was explained by the variance of the selected categories of demographic characteristics. However, an analysis of the coefficients of correlation between the employment efficiency index and the individual categories of demographic characteristics points clearly to the fact that some of the categories had a far stronger impact on the studied index in the given Voivodeship. The categories that across the Voivodeships had a significant impact on the level of the employment efficiency index the most frequently were:

- share of unemployed persons aged 55-64 remaining jobless for more than 12 months in the total 55-64-year-old unemployed population $\left(X_{12}\right)$,

- share of unemployed persons with junior high school or lower education in the total unemployed population $\left(X_{4}\right)$,

- share of unemployed persons remaining jobless for over 24 months in the total unemployed population $\left(X_{9}\right)$,

- share of unemployed persons aged 55-64 remaining jobless for more than 12 months in the total unemployed population $\left(X_{11}\right)$,

- share of unemployed persons without qualifications (without seniority) in the total unemployed population $\left(X_{13}\right)$. 


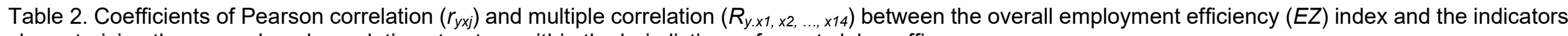
characterizing the unemployed population structure within the jurisdictions of county labor offices

\begin{tabular}{|c|c|c|c|c|c|c|c|c|c|c|c|c|c|c|c|}
\hline \multirow{2}{*}{$\begin{array}{c}\text { Voivodeship } \\
\text { (no. of county labor offices) }\end{array}$} & \multicolumn{14}{|c|}{ Coefficients of Pearson correlation between the $E Z$ and the indicators } & \multirow{2}{*}{$R$} \\
\hline & $X_{1}$ & $X_{2}$ & $X_{3}$ & $X_{4}$ & $X_{5}$ & $X_{6}$ & \begin{tabular}{|l|}
$X_{7}$ \\
\end{tabular} & $X_{8}$ & $X_{9}$ & $X_{10}$ & $X_{11}$ & $X_{12}$ & $X_{13}$ & $X_{14}$ & \\
\hline Dolnośląskie (26) & 0.179 & 0.012 & -0.004 & -0.232 & 0.150 & 0.001 & 0.046 & -0.132 & -0.290 & -0.034 & -0.329 & -0.340 & -0.129 & 0.434 & 0.755 \\
\hline Kujawsko-pomorskie (20) & 0.084 & -0.010 & 0.265 & -0.216 & -0.191 & 0.496 & -0.121 & 0.099 & -0.096 & -0.235 & 0.324 & 0.003 & -0.616 & 0.040 & 0.968 \\
\hline Lubelskie (21) & -0.078 & 0.036 & 0.195 & 0.050 & -0.157 & 0.210 & 0.001 & 0.027 & 0.057 & -0.060 & 0.270 & 0.215 & -0.342 & 0.032 & 0.890 \\
\hline Lubuskie (12) & -0.014 & 0.341 & -0.280 & 0.140 & -0.123 & 0.054 & -0.138 & -0.487 & -0.492 & -0.336 & -0.321 & -0.335 & -0.179 & 0.162 & $\mathrm{X}$ \\
\hline Łódzkie (22) & 0.403 & 0.274 & 0.300 & -0.393 & 0.164 & -0.175 & 0.436 & -0.225 & 0.062 & 0.237 & -0.177 & -0.133 & -0.086 & -0.054 & 0.831 \\
\hline Małopolskie (21) & 0.420 & -0.344 & 0.549 & -0.512 & 0.519 & -0.559 & 0.479 & -0.040 & -0.339 & 0.106 & -0.645 & -0.298 & -0.192 & 0.069 & 0.910 \\
\hline Mazowieckie (39) & 0.284 & 0.042 & -0.020 & -0.119 & 0.288 & -0.009 & 0.210 & -0.385 & -0.351 & -0.047 & -0.230 & -0.331 & 0.044 & 0.325 & 0.774 \\
\hline Opolskie (11) & 0.034 & 0.274 & 0.095 & -0.496 & 0.269 & 0.154 & 0.680 & 0.135 & -0.509 & -0.005 & -0.276 & -0.339 & -0.394 & 0.195 & $\mathrm{x}$ \\
\hline Podkarpackie (21) & -0.240 & -0.314 & 0.284 & 0.275 & -0.020 & 0.224 & 0.184 & -0.129 & 0.182 & 0.156 & 0.342 & 0.100 & -0.279 & -0.098 & 0.735 \\
\hline Podlaskie (14) & -0.004 & 0.005 & 0.087 & -0.240 & 0.369 & -0.426 & -0.095 & -0.144 & 0.215 & 0.340 & -0.121 & 0.454 & 0.324 & -0.184 & $\mathrm{x}$ \\
\hline Pomorskie (17) & 0.022 & 0.227 & -0.149 & -0.327 & 0.118 & -0.062 & 0.110 & -0.293 & -0.246 & -0.169 & -0.105 & -0.092 & 0.064 & -0.283 & 0.874 \\
\hline Śląskie (31) & -0.090 & 0.396 & 0.085 & -0.441 & 0.232 & -0.046 & 0.190 & -0.094 & -0.016 & 0.042 & -0.110 & -0.108 & -0.191 & 0.019 & 0.797 \\
\hline Świętokrzyskie (14) & 0.307 & 0.018 & -0.210 & -0.095 & -0.084 & 0.399 & -0.318 & 0.038 & 0.113 & -0.059 & 0.280 & 0.004 & -0.234 & 0.142 & $x$ \\
\hline Warmińsko-mazurskie (20) & 0.491 & 0.282 & -0.490 & -0.108 & 0.271 & -0.182 & -0.080 & -0.134 & -0.220 & 0.101 & -0.252 & -0.207 & -0.260 & 0.302 & 0.921 \\
\hline Wielkopolskie (31) & 0.205 & 0.133 & 0.036 & -0.326 & -0.024 & 0.256 & 0.068 & 0.093 & 0.065 & -0.064 & 0.148 & -0.013 & 0.009 & 0.245 & 0.720 \\
\hline Zachodniopomorskie (20) & 0.035 & 0.046 & -0.340 & 0.168 & 0.013 & -0.229 & -0.020 & 0.066 & 0.493 & 0.079 & 0.230 & 0.415 & 0.398 & -0.509 & 0.913 \\
\hline Poland (340) & 0.011 & 0.130 & 0.014 & -0.263 & 0.124 & -0.005 & 0.128 & -0.072 & -0.042 & -0.008 & -0.026 & -0.016 & -0.065 & 0.073 & 0.406 \\
\hline $\begin{array}{l}\text { No. of Voivodeships with the } \\
\text { given indicator impacting the } \\
E Z \text { significantly }\end{array}$ & 4 & 4 & 4 & 6 & 2 & 4 & 4 & 2 & 5 & 2 & 5 & 7 & 5 & 4 & \\
\hline $\begin{array}{l}\text { Dominating direction of the } \\
\text { given indicator's impact on } \\
\text { the } E Z\end{array}$ & + & + & + & - & + & - & + & - & - & - & - & - & - & + & \\
\hline
\end{tabular}

Source: Authors' own calculations based on MRPiPS (Ministry of Family, Labor and Social Policy) and BDL GUS (Statistics Poland's Local Data Bank) data.

$X$ - for these Voivodeships no multiple correlation coefficient was calculated since the number of independent variables (the indicators characterizing the unemployed population structure) was either larger than or equal to the number of observations (the number of county labor offices operating within the given Voivodeship). 
The categories that had a significant impact on the level of the employment efficiency index the least frequently were:

- share of unemployed persons aged 24 or less in the total unemployed population $\left(X_{5}\right)$,

- share of unemployed persons remaining jobless for 12 to 24 months in the total unemployed population $\left(X_{8}\right)$,

- share of unemployed persons aged 18-24 remaining jobless for more than 6 months in the total unemployed population $\left(X_{10}\right)$.

A description of county labor offices operating within the individual Voivodeships according to the strength and direction of impact of selected demographic characteristic categories on the overall employment efficiency (EZ) index is shown in Table 3.

Table 3. Description of county labor offices in Voivodeships according to how the indicators characterizing the unemployed population structure impacted the overall employment efficiency $(E Z)$ index

\begin{tabular}{|c|c|c|}
\hline Voivodeship & $\begin{array}{l}\text { Set of indicators having } \\
\text { a definite impact on the } \\
\qquad E Z^{\mathrm{a}}\end{array}$ & $\begin{array}{l}\text { County labor offices according to the strength and direction } \\
\text { of selected indicators' impact on the } E Z\end{array}$ \\
\hline Dolnośląskie & $X_{11}(-), X_{12}(-), X_{14}(+)$ & $\begin{array}{l}\text { A higher employment efficiency was observed for those la- } \\
\text { bor offices that had a higher share of disabled unemployed } \\
\text { people. A lower efficiency was noted for those offices that } \\
\text { had a higher share of 55-64-year-old unemployed people } \\
\text { remaining jobless for more than } 12 \text { months }\end{array}$ \\
\hline Kujawsko-pomorskie & $X_{6}(+), X_{11}(+), X_{13}(-)$ & $\begin{array}{l}\text { A higher employment efficiency was observed for those la- } \\
\text { bor offices that had a higher share of unemployed people } \\
\text { aged } 55 \text { or more and a higher share of } 55-64 \text {-year-old un- } \\
\text { employed people remaining jobless for more than } 12 \\
\text { months. A lower efficiency was noted for those offices that } \\
\text { had a higher share of unqualified unemployed people }\end{array}$ \\
\hline Lubelskie & $X_{13}(-)$ & $\begin{array}{l}\text { A lower employment efficiency was observed for those labor } \\
\text { offices that had a higher share of unqualified unemployed } \\
\text { people }\end{array}$ \\
\hline Lubuskie & $\begin{array}{l}X_{2}(+), X_{8}(-), X_{9}(-), X_{10}(-) \\
X_{11}(-), X_{12}(-)\end{array}$ & $\begin{array}{l}\text { A higher employment efficiency was observed for those la- } \\
\text { bor offices that had a higher share of unemployed people } \\
\text { with tertiary education, and a lower efficiency for those that } \\
\text { had a higher share of long-term unemployed people, both } \\
\text { aged } 18-24 \text { and 55-64 }\end{array}$ \\
\hline Łódzkie & $X_{1}(+), X_{3}(+), X_{4}(-), X_{7}(+)$ & $\begin{array}{l}\text { A higher employment efficiency was observed for those la- } \\
\text { bor offices that had a higher share of unemployed women, } \\
\text { unemployed people with basic vocational education, and un- } \\
\text { employed people domiciled in rural areas. A lower efficiency } \\
\text { was noted for those offices that had a higher share of unem- } \\
\text { ployed people with junior high school or lower education }\end{array}$ \\
\hline Małopolskie & $\begin{array}{l}X_{1}(+), X_{2}(-), X_{3}(+), X_{4}(-) \\
X_{5}(+), X_{6}(-), X_{7}(+), X_{9}(-) \\
X_{11(-)}, X_{12}(-)\end{array}$ & $\begin{array}{l}\text { A higher employment efficiency was observed for those la- } \\
\text { bor offices that had a higher share of unemployed women, } \\
\text { unemployed people with basic vocational education, unem- } \\
\text { ployed people aged } 24 \text { or less, and unemployed people } \\
\text { domiciled in rural areas. A lower efficiency was noted for } \\
\text { those offices that had a higher share of unemployed people } \\
\text { with tertiary education or junior high school or lower educa- } \\
\text { tion, unemployed persons aged } 55 \text { or more, and long-term } \\
\text { unemployed people }\end{array}$ \\
\hline Mazowieckie & $X_{8}(-), X_{9}(-), X_{12}(-), X_{14}(+)$ & $\begin{array}{l}\text { A higher employment efficiency was observed for those la- } \\
\text { bor offices that had a higher share of disabled unemployed } \\
\text { people. A lower efficiency was noted for those offices that } \\
\text { had a higher share of long-term unemployed people }\end{array}$ \\
\hline
\end{tabular}


Table 3. Description of county labor offices in Voivodeships according to how the indicators characterizing the unemployed population structure impacted the overall employment efficiency $(E Z)$ index (cont.)

\begin{tabular}{|c|c|c|}
\hline Voivodeship & $\begin{array}{l}\text { Set of indicators having } \\
\text { a definite impact on the } \\
\qquad E Z^{a}\end{array}$ & $\begin{array}{l}\text { County labor offices according to the strength and direction } \\
\text { of selected indicators' impact on the } E Z\end{array}$ \\
\hline Opolskie & $\begin{array}{l}X_{4}(-), X_{7}(+), X_{9}(-), X_{12}(-) \\
X_{13}(-)\end{array}$ & $\begin{array}{l}\text { A higher employment efficiency was observed for those la- } \\
\text { bor offices that had a higher share of unemployed people } \\
\text { domiciled in rural areas. A lower efficiency was noted for } \\
\text { those offices that had a higher share of unemployed people } \\
\text { with junior high school or lower education, long-term unem- } \\
\text { ployed people (including those aged 55-64) and unqualified } \\
\text { unemployed people }\end{array}$ \\
\hline Podkarpackie & $X_{2}(-), X_{11}(-)$ & $\begin{array}{l}\text { A lower employment efficiency was observed for those labor } \\
\text { offices that had a higher share of unemployed people with } \\
\text { tertiary education and 55-64-year-old unemployed people } \\
\text { remaining jobless for more than } 12 \text { months }\end{array}$ \\
\hline Podlaskie & $\begin{array}{l}X_{5}(+), X_{6}(-), X_{10}(+) \\
X_{12}(+), X_{13}(+)\end{array}$ & $\begin{array}{l}\text { A higher employment efficiency was observed for those la- } \\
\text { bor offices that had a higher share of unemployed people } \\
\text { aged } 24 \text { or less, long-term unemployed people and unqual- } \\
\text { ified unemployed people. and unemployed people domiciled } \\
\text { in rural areas. A lower efficiency was noted for those offices } \\
\text { that had a higher share of unemployed persons aged } 55 \text { or } \\
\text { more }\end{array}$ \\
\hline Pomorskie & $X_{4}(-)$ & $\begin{array}{l}\text { A lower employment efficiency was observed for those labor } \\
\text { offices that had a higher share of unemployed people with } \\
\text { junior high school or lower education }\end{array}$ \\
\hline Śląskie & $X_{2}(+), X_{4}(-)$ & $\begin{array}{l}\text { A higher employment efficiency was observed for those la- } \\
\text { bor offices that had a higher share of unemployed people } \\
\text { with tertiary education, and a lower efficiency for those that } \\
\text { had a higher share of unemployed people with junior high } \\
\text { school or lower education }\end{array}$ \\
\hline Świętokrzyskie & $X_{1}(+), X_{6}(+), X_{7}(-)$ & $\begin{array}{l}\text { A higher employment efficiency was observed for those la- } \\
\text { bor offices that had a higher share of unemployed women } \\
\text { and unemployed people aged } 55 \text { or more. A lower efficiency } \\
\text { was noted for those offices that had a higher share of unem- } \\
\text { ployed people from rural areas }\end{array}$ \\
\hline $\begin{array}{l}\text { Warmińsko-mazur- } \\
\text { skie }\end{array}$ & $X_{1}(+), X_{3}(-), X_{14}(+)$ & $\begin{array}{l}\text { A higher employment efficiency was observed for those la- } \\
\text { bor offices that had a higher share of unemployed women } \\
\text { and disabled unemployed people. A lower efficiency was } \\
\text { noted for those offices that had a higher share of unem- } \\
\text { ployed people with basic vocational education }\end{array}$ \\
\hline Wielkopolskie & $X_{4}(-)$ & $\begin{array}{l}\text { A lower employment efficiency for those labor offices that } \\
\text { had a higher share of unemployed people with junior high } \\
\text { school or lower education }\end{array}$ \\
\hline Zachodniopomorskie & $\begin{array}{l}X_{3}(-), X_{9}(+), X_{12}(+) \\
X_{13}(+), X_{14}(-)\end{array}$ & $\begin{array}{l}\text { A higher employment efficiency was observed for those la- } \\
\text { bor offices that had a higher share of long-term unemployed } \\
\text { people and unqualified unemployed people. A lower effi- } \\
\text { ciency for those that had a high share of unemployed people } \\
\text { with basic vocational education and disabled unemployed } \\
\text { people }\end{array}$ \\
\hline
\end{tabular}

aThe brackets at individual indicators contain information on the direction of the indicator's impact on the overall employment efficiency index.

Source: Developed by the authors based on Table 2. 


\section{CONCLUSION}

Both general and detailed conclusions can be drawn from the study presented herein. The general conclusions are based on comparisons between the results obtained for the whole country (all the county labor offices) and for the individual voivodeships, whereas the detailed conclusions are based on comparisons between regularities identified for the individual voivodeships.

The most important general conclusions include:

1) a considerably weaker correlation between the indicators for the whole country (all the county labor offices) than for the individual Voivodeships;

2) at the national level, none of the selected indicators characterizing the unemployed population structure had a significant impact on the overall employment efficiency index, although at the level of individual Voivodeships certain indicators - or at least one indicator - that had a significant impact on the employment efficiency index could be identified;

3 ) although there were no indicators having a considerable impact on the $E Z$ index at the national level, it was noticed that the directions of their impact on the $E Z$ index were concordant with the dominating direction of impact of the given indicator in the individual Voivodeships.

The aforementioned general conclusions confirm the principle that certain regularities are easier to describe for smaller groups that are more homogeneous with regard the studied aspect. This, in turn, indicates that when looking for regularities in the relationships between employment efficiency and indicators characterizing the unemployed according to selected categories of demographic characteristics, the specificity of the jurisdiction of the county labor offices must be accounted for. The foregoing claim is confirmed by the following detailed conclusions drawn from the study:

1) most Voivodeships have different sets of indicators having a significant impact on the level of the overall employment efficiency index - with the exception of Pomorskie and Wielkopolskie Voivodeships, where only one indicator related to the unemployed persons' education had a significant impact; in these Voivodeships, the lower overall employment efficiency index in the county labor offices resulted from their high share of unemployed persons with junior high school or lower education, i.e. low-educated unemployed persons unfortunately do not undertake employment even despite participating in various forms of vocational stimulation;

2) for the other fourteen Voivodeships, the number of indicators affecting the $E Z$ index varied substantially, ranging from one (Lubelskie Voivodeship) to ten (Małopolskie Voivodeship);

3 ) notably, the indicator $X_{12}$ (share of 55-64-year-old unemployed persons remaining jobless for more than 12 months) was the one that affected the employment efficiency index in the county labor offices operating within the individual Voivodeships the most frequently - its significant impact on the $E Z$ index was observed for the county labor offices operating in seven Voivodeships, with the impact being negative in five and positive in two of them;

4 ) three indicators affected the employment efficiency index the least frequently: share of unemployed persons aged 24 or less in the total unemployed population $\left(X_{5}\right)$, share of unemployed persons remaining jobless for 12 to 24 months in the total unemployed population $\left(X_{8}\right)$, share of unemployed persons aged 18-24 remaining jobless for more than 6 months 
in the total unemployed population $\left(X_{10}\right)$ - their significant impact was only observed for one $\left(X_{8}\right.$ - a negative impact on the $\left.E Z\right)$ or two Voivodeships $\left(X_{5}-\right.$ a positive impact in both Voivodeships, $X_{10}$ - a positive impact in one Voivodeship, a negative one in the other).

While analyzing the detailed conclusions it must be highlighted that no single identical set of indicators could be identified for all the Voivodeships. Even where the set included the same indicators, they often differed with regard to the direction with which they impacted the employment efficiency index. Although no unequivocal results in terms of the strength and direction of impact of the indicators describing the unemployed population structure on employment efficiency could be found, the authors believe that conducting this type of research is substantiated. An ability to detect the differences existing in the individual county and voivodeship labor markets is of great significance not only for the sake of getting to know the current situation but also for determining the directions for further changes to be introduced in respect of, inter alia, the range of the major vocational stimulation forms offered by county labor offices to the registered unemployed.

Finally, it should be stressed that this study showed clearly that the impact of the unemployed population structure on the overall employment efficiency index differed between the Voivodeships and the country as a whole. Therefore, when assessing the operational efficiency of county labor offices, it is necessary that the specificity of the area of jurisdiction of the given labor office should be taken into account.

\section{REFERENCES}

Analiza rozwiązań, o których mowa $w$ art. 108 ust. $1 \mathrm{i}$ ustawy o promocji zatrudnienia $\mathrm{i}$ instytucjach rynku pracy. 2017. Warszawa, Ministerstwo Rodziny, Pracy i Polityki Społecznej Departament Funduszy Wydział Wydatków Fakultatywnych i Analiz Efektywności, https://www.mpips.gov.pl/ analizy-i-raporty/raporty-sprawozdania/rynek-pracy/, access: 25.09.2018. [in Polish]

Badanie ilościowe w powiatowych urzędach pracy. 2018. Raport badawczy do projektu pt.: Wypracowanie metodologii i wdrożenie monitorowania efektywności zatrudnieniowej podstawowych form aktywizacji zawodowej bezrobotnych w okresie dłuższym niż 12 miesięcy od zakończenia działań urzędu pracy. Katowice, Stowarzyszenie Czas. Przestrzeń. Tożsamość. Grupa BST Sp. z o.o. [in Polish]

Bąk I., Markowicz I., Mojsiewicz M., Wawrzyniak K. 2018. Wzory i tablice. Metody statystyczne i ekonometryczne. Warszawa, CeDeWu Sp. z o.o., 12. [in Polish]

Bąk I., Wawrzyniak K., Sobolewski A. 2018. Przestrzenne zróżnicowanie sytuacji społeczno-gospodarczej a efektywność zatrudnieniowa w powiatowych urzędach pracy w Polsce [The spatial diversity of socio-economic situation and the employee efficiency in district labor office in Poland]. Folia Pomer. Univ. Technol. Stetin., Oeconomica 347(93)4, 17-28. [in Polish]

Bieszk-Stolorz B., Dmytrów K. 2018. Efektywność form aktywizacji zawodowej w przekroju wojewódzkim [Effectiveness of forms of professional activation by voivodship]. Wiad. Statyst. 12(691), 57-74. [in Polish]

Cicha-Nazarczuk M. 2015. Regionalne zróżnicowanie finansowania i efektywności aktywnej polityki rynku pracy w Polsce [Regional disparities in effectiveness and funding of active labour market policy in Poland]. Optimum. Stud. Ekonom. 4(76), 153-168. [in Polish]

Efektywność podstawowych form aktywizacji zawodowej, realizowanych w ramach programów na rzecz promocji zatrudnienia, łagodzenia skutków bezrobocia i aktywizacji zawodowej w 2018 roku. 2019. Warszawa, Ministerstwo Rodziny, Pracy i Polityki Społecznej, Departament Funduszy, https://www.gov.pl/web/rodzina/efektywnosc-form-promocji-zatrudnienia, access: 24.10.2019. [in Polish] 
Efektywność polityki rynku pracy w Polsce. 2011. Red. Z. Wiśniewski, K. Zawadzki. Toruń, Wojewódzki Urząd Pracy, UMK. [in Polish]

Efektywność usług $i$ instrumentów rynku pracy służących podnoszeniu kwalifikacji bezrobotnych w Polsce i wybranych krajach Unii Europejskiej. 2008. Red. P. Błędowski. Warszawa, Ministerstwo Pracy i Polityki Społecznej, Departament Rynku. [in Polish]

Escudero V. 2015. Are active labour market policies effective in activating and integrating low-skilled individuals? An international comparison. Paris School Econ. Work. Pap. 1, https://halshs.archivesouvertes.fr/halshs-01105347/document, access: 26.04.2019.

Góralski A. 1976. Metody opisu i wnioskowania statystycznego w psychologii. Warszawa, PWN, 34. [in Polish]

Gruszczyński L.A. 1986. Elementy statystyki dla socjologów. Katowice, Uniwersytet Śląski, 168. [in Polish]

Guilford J.P. 1964. Podstawowe metody statystyczne w psychologii i pedagogice. Warszawa, PWN, 157. [in Polish]

Kluve J. 2006. The effectiveness of European active labor market policy. IZA Discussion Paper Series, 2018, http://ftp.iza.org/dp2018.pdf, access: 26.04.2019.

Kluve J., Fertig M., Jacobi L., Nima L., Schaffner S., Schmidt Ch., Card D., Góra M., Jensen P., Leetmaa R., Patacchini E., Klaauw B. van der, Weber A. 2005. Study on the effectiveness of ALMPs: Research project for the European Commission, DG Employment, Social Affairs and Equal Opportunities. Final report, RWI - Leibniz - Institut für Wirtschaftsforschung, http://www.rwi-essen.de/media/content/pages/publikationen/rwi - projektberichte/PB_ALMP.pdf, access: 26.04.2019.

Knapińska M. 2015. Efektywność polityki rynku pracy - aspekty teoretyczne i praktyczne [Effectiveness of labor market policy - theoretical and practical aspects]. Pr. Nauk. UE Wroc. 401, 187-197.

Luszniewicz A., Słaby T. 2003. Statystyka z pakietem komputerowym STATISTICA PL. Teoria i zastosowania. Warszawa, Wydaw. C.H. Beck, 287, 291. [in Polish]

Metody i narzędzia badania efektywności aktywnej polityki rynku pracy. 2012. Red. M. Maksim, Z. Wiśniewski. Warszawa, Centrum Rozwoju Zasobów Ludzkich. [in Polish]

Reichelt A. 2007. Regionalne zróżnicowanie efektywności aktywnych programów rynku pracy w Polsce [Regional differences in the effectiveness of active labour market programmes in Poland]. Ruch Praw. Ekonom. Socjol. 69(3), 153-170. [in Polish]

Statystyka. 2005. Red. J. Paradysz. Poznań, Wydaw. AE Pozn., 229-230, 233, 268. [in Polish]

Ustawa z dnia 20 kwietnia 2004 r. o promocji zatrudnienia i instytucjach rynku pracy. DzU z 2019 r., poz. 1482 z późn. zm. [in Polish]

Zając K. 1982. Zarys metod statystycznych. Warszawa, PWE, 298. [in Polish]

\title{
WPŁYW STRUKTURY BEZROBOTNYCH NA POZIOM WSKAŹNIKA EFEKTYWNOŚCI ZATRUDNIENIOWEJ
}

\begin{abstract}
Streszczenie. Celem artykułu jest sprawdzenie, w jakim stopniu struktura zarejestrowanych bezrobotnych według wybranych kategorii cech demograficznych wpływa na poziom wskaźnika efektywności zatrudnieniowej. Jako narzędzia badawcze zastosowano współczynniki korelacji Pearsona oraz korelacji wielorakiej pomiędzy wskaźnikiem efektywności zatrudnieniowej a cechami demograficznymi. Współczynniki te obliczono dla powiatowych urzędów pracy funkcjonujących na terenie poszczególnych województw w 2018 roku, aby wykryć prawidłowości we współzależnościach tych wielkości w konkretnym województwie. Okazało się, że przeprowadzone badania nie dały jednoznacznych wyników. Siła zależności pomiędzy badanymi zmiennymi na poziomie kraju (wszystkie powiatowe urzędy pracy) jest znacznie niższa niż na poziomie poszczególnych województw. W każdym województwie zestaw cech demograficznych mających znaczny wpływ na poziom wskaźnika efektywności zatrudnieniowej jest odmienny i różni się często kierunkiem odziaływania.
\end{abstract}

Słowa kluczowe: analiza korelacji, powiatowe urzędy pracy, struktura bezrobotnych, wskaźnik efektywności zatrudnieniowej. 
